\title{
TWO GREEK INSCRIPTIONS FROM
} KHURBET ḤARRAWI.

\author{
By Dr. E. W. G. Masterman.
}

ONE of the most remarkable hills in Galilee is that isolated, steep, and very conspicuous one which stands immediately over 'Ain el Melähah. It is mentioned in the Memoirs and marked in the P.E.F. Map as Khurbet Harrah but Harräwi appears to be the name by which it is universally known to-day, and Guérin speaks of it as Tell el Harrawi. The hill is striking whether viewed from the mountains around Safed in the south or from the higher ground round Merj 'Ayłin in the north; it stands out boldly and conspicuously when Western Palestine is surveyed from the Jaulan or the slopes of Hermon; it dominates the scene on the whole ride along the Huleh valley on the road to Banias. Even from the top of the Jebal Jermak it is, though from there so far below, a striking object. There is no clear proof that it is the site of Hazor, but it is manifestly the most likely site for an ancient fortified city near the Huleh, and answers better than any other suggested site to the description of Josephus, ${ }^{1}$ and the remains on the surface are extensive and some at least of the walls are probably ancient. There is much early pottery about. The neighbouring Kh. Khureibeh, which we passed on the road to Deishin, has no claim to be Hazor compared with this place. It is not, however, correct to say, as is stated in the Ency. Bib. (article "Hazor"), that "no ruins have yet been discovered there." There are extensive ruins but composed of small stones: there are no traces of important buildings.

On September 21 st I made a visit to this site, riding from Safed vid the mediaeval Arab site of Khurbet Benit (with a magnificent view), the Roman site Khurbet Maras, and the Hebro-Roman Khurbet Keisiin. With considerable stops at these places we took seven hours on the way. We returned by the more direct inland way via Deishin, 'Alma, and 'Ain ez Zeitun, in four and a half hours.

$$
{ }^{1} \text { Ant., } \mathrm{V}, 5, \S 1 .
$$


The ascent of the Tell Harrawi is exceedingly steep on all sides. We ascended along the southern aspect by a rough path. Where the path comes out on the tell - the lowest part of the summit-is a large platform made of massive stones and some dry cisterns. A little more to the east are remains of what may have been a city or fortress wall. About the centre of the summit is a ruin, on the southern side of which stand two much weather-worn door-posts. Immediately inside this someone has dug a hole in the ground and has, from here apparently, extracted a large stone which lies on the ground in the neighbourhood. This stone must have been entirely buried and protected since the moment when it fell from its original position, for it is as fresh and sharply-cut as if it had been made this year. The stone is 4 feet $\times 1$ foot 11 inches and 7 inches thick,

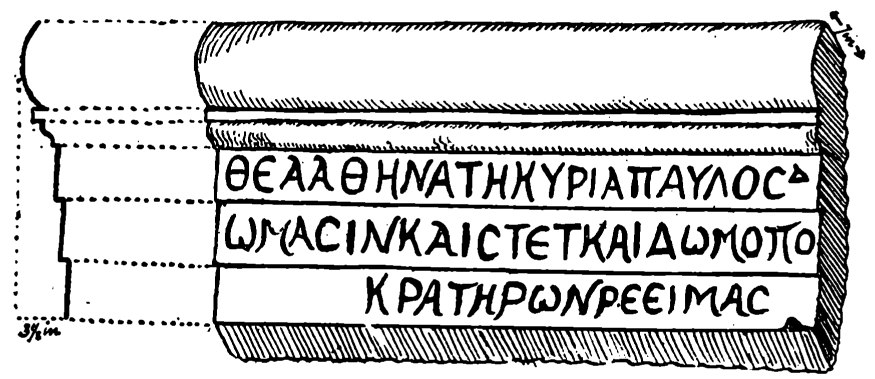

Fra. 1.-Inscriptions on Lintel of Temple Door at Khurbet Harrawi.

and from its general shape clearly must have been the lintel above a door: the letters of the inscription were sharp, distinct, and as if new. It appears clear, from the wording of the inscription, that the ruin from which this was rescued was a sanctuary of Athena and, if so, it is an illustration of how dangerous it is to judge of the extreme antiquity of buildings from the worn conditions of their stones (fig. 1). The limestone of Palestine weathers fastsome kinds extremely so-and it is quite impossible to date anything from this alone. The stones of this building are so rough and worn that they appear to have never been hewn; yet one of them, unearthed a few feet down, shows that these very stones were once most carefully chiselled. Close to this old sanctuary is a modern but now ruined stable built of old materials, and more to the west-on the summit of the tell-are two modern 
buildings fast dropping to pieces. One has the appearance of having been a kind of kiosk, the other is a ruined house with a central court and six rooms - three on each side. It is built chiefly of old materials. I was informed by my companion, Mr. Nassâr of Safed, that some people took up their abode on this hill a few years ago but left it hurriedly soon after the occurrence of a murder in the neighbourhood.

Built in, upside down, over the door of one of the northern rooms, I found a fragment of inscribed stone (fig. 2). As it was but an hour or so before sunset, and I was informed that the neighbourhood was very insecure, I could not stay to give this the attention

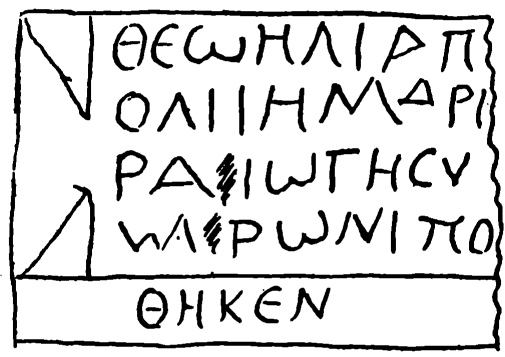

Fig. 2.-Fragment of Inscribed Stone at Khurbet Hiarrawi.

I should have liked, and an attempt to take a make-shift squeeze (with ordinary paper and cold tea!) having been spoiled by the stormy west wind, I had to be content with making as careful a copy as possible and taking a rough rubbing. These I send. Mr. Macalister has made a few emendations suggested by the rubbing. ${ }^{1}$

1 [No. 1 commences, as Canon Hicks kindly points out, $\theta \in \tilde{a} \tilde{a}$ 'A $\theta$ hrạ $\tau \tilde{y}$ kvpía

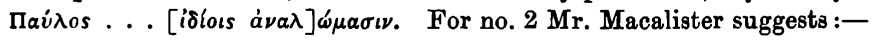

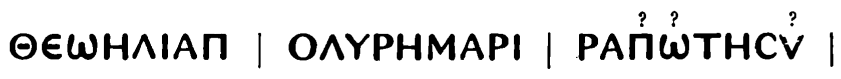 MAPWNYחO |}

The lust line is clearly $(\dot{a} \nu \dot{\varepsilon}) \theta \eta \kappa \epsilon \nu$.] 